\title{
Chapter 5 \\ Stagnation and Dynamism in Three Supply \\ Chains: Agriculture and Foods, Building \\ Materials and Construction, Energy
}

\author{
Harry Lintsen
}

\section{Contents}

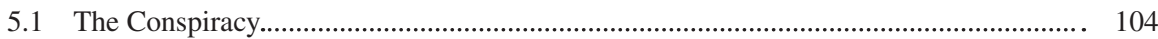

5.2 Agriculture and Foods: More of the Same

5.3 Building Materials and Construction: King and State................................................ 112

5.3.1 Public Housing and Public Health...................................................................... 112

5.3.2 Water Management............................................................................................ 115

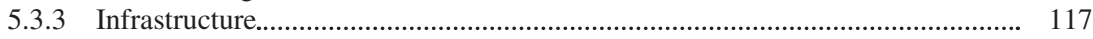

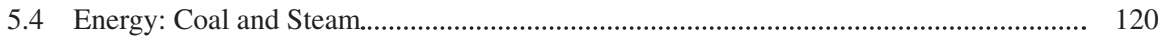

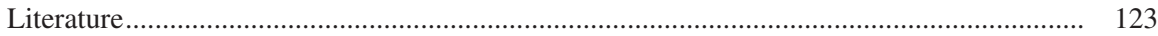

Abstract At the time, extreme poverty could be fought by, among other things, economic growth. That demanded another approach to the exploitation of natural capital and accordingly to innovation in the three main supply chains.

In the agriculture and foods supply chain (one of the three main chains in this study, based on organic raw materials) experimentation with new techniques did take place (among other things the use of guano as artificial fertilizer) but this did not lead to practical innovations.

In the supply chain of building materials and construction (the second main chain based on mineral subsoil resources) the construction of a national road system amounted to an important innovation in road infrastructure. Hardly any innovations were undertaken in the fields of water management and housing construction. It is remarkable that little was done about the social problem of organic wastes, including human and animal faeces. Public hygiene was not one of the most important societal issues of the time.

In the energy supply chain (the third main supply chain based on fossil subsoil resources) innovations were equally lacking, in particular applications of steam power. Up to 1850 the Netherlands did not industrialise on the basis of steam and coal.

Keywords Innovation - Agriculture - Foods - Construction - Water management · Infrastructure $\cdot$ Hygiene $\cdot$ Energy $\cdot$ Industrialisation $\cdot$ Steam technology 


\subsection{The Conspiracy ${ }^{1}$}

On January 311827 Lodewijk Cantillon submitted a request to King William I for permission to build a steam-powered gristmill in Amsterdam, the first in the Northern Netherlands. Cantillon was a grain merchant from Hasselt, which town at the time belonged to the Southern Netherlands. The procedure required consultation with the surrounding neighbors. These were dead set against the project because of the danger of 'explosion of the boiler, the danger of fire and other unpredictable disasters...' They also feared that the value of their real estate would plummet due to the 'thick clouds of coal smoke, the bad smell, the noise of the machine, even the multiplication of rats and other vermin attracted by the grain...'2

The wind-powered grist-millers also objected. They feared 'the total ruin' of Amsterdam's wind-powered milling industry, that counted 34 windmills and fed 170 households. The steam gristmill would have 'unhappy consequences' for the millers with their 'so dearly bought buildings,' but also for the government because the windmill industry paid significant taxes and these could then no longer be levied. ${ }^{3}$

The city of Amsterdam also opposed the plan. It observed that the 'location where the construction is requested is the most beautiful and prestigious part of that quarter of the city.' ${ }^{\prime 4}$ Steam engines did not belong in the girdle of canals but in lesser neighbourhoods. The city also supported the grievance of the millers. Amsterdam did not need competition for the existing milling industry. Let Cantillon apply his energy and inventiveness in a better way, was the city's final word.

But King William, proponent of a liberal economy that he was, granted Cantillon's request, albeit after Cantillon had found a new location and submitted a new request. To attract customers, Cantillon tried to cut his milling rates to an absolute minimum. The going rate in Amsterdam was about 39 eurocent for milling one hectoliter of wheat and almost 38 eurocent for an hectoliter of rye. Cantillon asked about 33 eurocents and 23 eurocents, respectively. The windmillers retaliated at once. They began to undercut Cantillon's prices. The bakers were loyal to the windmillers and refused to let Cantillon grind their grain. Cantillon tried to turn the tide and to come

\footnotetext{
${ }^{1}$ See for the Cantillon episode: H. Lintsen et al., Made in Holland: Een techniekgeschiedenis van Nederland [1800-2000] (Zutphen 2005), 33-36; H. Lintsen and M. Bakker, 'Meel', in: H. Lintsen et al. (Eds.), 'Geschiedenis van de techniek in Nederland. De wording van een moderne samenleving 1800-1890 (Zutphen 1993), Part 1, 70-101, in particular 81-84; J.L van Zanden and A. Van Riel, Nederland 1780-1914: Staat, instituties en economische ontwikkeling (Amsterdam 2000), $178-185$.

${ }^{2}$ Gemeentearchief Amsterdam, Archief Secretarie-Afdeling Financiën, 1827, nr. 725, Brief van 17 eigenaren aan de burgemeester van de stad Amsterdam (Letter of 17 proprietors to the mayor of Amsterdam), 13 March 1827.

${ }^{3}$ Gemeentearchief Amsterdam, Archief Secretarie-Afdeling Financiën, 1827, nr. 1119, Brief van zeven molenaars aan de Koning (Letter of seven millers to the King).

${ }^{4}$ Gemeentearchief Amsterdam, Archief Secretarie-Afdeling Financiën, 1827, nr. 927, brief van de commissaris over de publieke werken aan de wethouder van financiën, 28 maart 1827 (Letter of the commissioner of public works to the alderman of finances, 28 March, 1827).
} 
to terms with the windmillers. But to no avail, they flatly refused. After this, the steam gristmill drops out of sight. Cantillon had failed.

In retrospect Cantillon's failure was a misfortune for the people of Amsterdam. His innovation would have lowered prices for flour and bread. That would have stimulated the consumption of bread as a staple food and improved the physical condition of the poor. About 30 years later the reformist Amsterdam physician Samuel Sarphati did succeed in decreasing the price of bread by $30 \%$. To do this he had to found the first (steam-powered) bread and flour factory (see Chap. 8). This had far-reaching consequences for the quality of life of the poor or, in terms of this book, for well-being in the Netherlands. Why did Cantillon fail?

With his innovative application of steam power Cantillon was in a good position to compete with the windmillers. He could grind grain considerably cheaper, but only if he succeeded in working at full capacity. If he fell much below this, his fixed costs began to prevail and to raise the unit milling costs. The Amsterdam windmillers knew exactly how to exploit this Achilles heel of large-scale production. Since time immemorial the millers had formed a mighty cartel, first in the form of a guild and after the abolition of guilds in 1798 in the form of a cooperative association. This cartel disposed over large sums of money that it employed to wage a price-war with Cantillon (and later with other steam-powered gristmills). The windmillers (in coalition with the bakers) were able to hold out long enough to run the steam gristmills out of business.

Cantillon's initiative signified a disturbance of the existing agricultural and food supply chain. That supply chain fulfilled a crucial function in the development of popular welfare for it shaped the production and consumption of primary foodstuffs, in particular porridge, bread and potatoes. In that supply chain the exploitation of the soil (natural capital), the processing of agricultural produce and the consumption of foodstuffs all had specific characteristics. The windmillers, for example - at least that is what Cantillon's case suggests - were dominant actors in the grain, flour and bread chain, who influenced the price and therefore the distribution of food. In so doing they also influenced the quality of life. The analysis of these supply chains is the business of this chapter. The focus is on poverty and vulnerability as the most important issues in well-being and sustainability around 1850.

Supply chains are a sequence of successive activities at specific locations and within certain organizations. They refer to the institutional framework of natural capital and their derivative material flows. We have divided the material flows into three main categories:

1. Biomass (agriculture and foods). The broad variety of supply chains and material flows in this category pertained mostly to foods (potatoes, grain, sugar beets, oil seeds, beans etc.) and additionally to industrial products (like wool, madder, leather and starch). We will elaborate on the food chain.

2. Mineral assets (building materials and construction). The supply chain for building materials was rooted in the exploitation of mineral raw materials like clay, sand, gravel and ores of iron, tin and zinc. Processing of mineral raw materials took place in the earthenware industry, in mining, in the metalworking industry 
and in construction. These products were used primarily in construction and for machines. We focus here on construction.

3. Fossil sub-soil assets (energy). The supply chains up to 1850 were limited to those for turf and coal. Here we concentrate on the coal supply chain.

We take these three categories as a point of departure for a brief analysis of stagnation and dynamism in the supply chains before 1850 . How could changes in the supply chains of production and consumption have supported sustainable development in the Netherlands. Which interventions in natural capital and the derivative material flows could have improved the quality of life of especially the poor? To what extent did innovations by contemporaries lead to transitions in the three supply chains?

\subsection{Agriculture and Foods: More of the Same}

In the first half of the nineteenth century, well-being was primarily a matter of quality of life and poverty. Food was a crucial element in the problematic situation, affecting especially the poor. Would they have access to enough food of sufficient quality throughout the year and in subsequent years? The poor were exceedingly vulnerable and faced a daily struggle to scrape a meagre meal together. A graph of food consumption confirms this image.

The average number of calories available to the Dutch in the period 1815-1850 was about $2400 \mathrm{kcal}$ per capita per day (see Graph 5.1). We can add a margin of about $10 \%$ for the calories contained in beverages, in particular beer that was consumed on a regular basis. Taken together, this exceeds the norm of 2000-2100 kcal/ day, that is universally taken to be the absolute minimum necessary to stay alive. ${ }^{5}$ The graph shows that the poor had a hard time of it. They ate no (or nearly no) meat. They fed themselves chiefly with potatoes, grain and dairy products. In the period under consideration, these foodstuffs delivered on average $2200 \mathrm{kcal}$ per day. But there were large fluctuations in the first half of the nineteenth century. There were years with less than $2000 \mathrm{kcal} /$ day. What the graph also hides is the unequal distribution of food. This makes the condition of the poor in certain periods even more problematic.

The first years of the century were a time of misery. This had everything to do with the political situation. ${ }^{6}$ The Napoleonic wars and the continental system wreaked havoc with food production and the food trade. In the $1820 \mathrm{~s}$ and $1830 \mathrm{~s}$ there was on average sufficient food available for the Dutch population. Nonetheless,

\footnotetext{
${ }^{5}$ R.C. Allen, Poverty lines in history, theory, and current international practice (Oxford 2013), discussion paper series ISSN 1471-0498, 3.

${ }^{6}$ For this see: M.T. Knibbe, 'De hoofdelijke beschikbaarheid van voedsel en de levensstandaard in Nederland, 1807-1913', Tijdschrift voor Sociale en Economische Geschiedenis 4(2007), nr. 4, 71-107.
} 


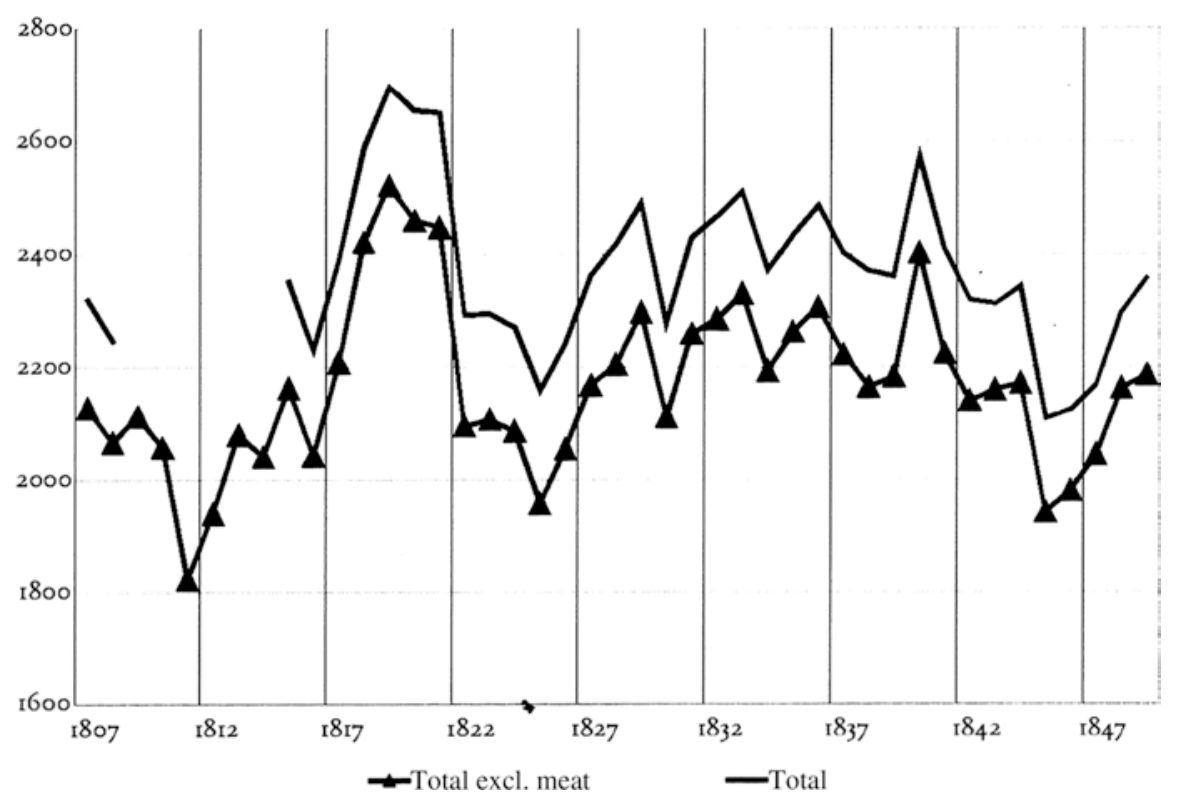

Graph 5.1 Daily amount of available kilocalories per capita including and excluding meat, 1807-1850

Source: Knibbe 2007

within this period there was at least one notoriously bad year, in which masses of the poor went hungry. 1845, 1846 and 1847 were again dramatic. Agricultural production declined in these years due to failed potato and rye harvests. Trade and industry stagnated. Under these circumstances the Dutch population was vulnerable. Food shortages ensued. The poor went hungry. For the first time that century the death rate outstripped the birth rate. The population declined.

But it was not only wars and crop failures that depressed food consumption. Between 1800 and 1850 the population increased by roughly 50\% (from 2,120,000 to 3,012,000 persons). The Netherlands faced the challenge of feeding all these mouths. International trade also affected the food situation. Increasing foreign demand, especially from industrialising England, did not go unnoticed. Domestic food patterns changed to suit. The Dutch enjoyed fewer dairy goods because butter and cheese were increasingly exported.

But at the same time, trade also provided a certain degree of food security. The Netherlands was self-sufficient only with respect to potatoes. Grain, particularly wheat and rye, had always been imported. When the domestic harvests of these bread grains failed, imports increased. ${ }^{7}$

Nutrition was an important factor in the physical and mental condition of the Dutch population. While exact criteria for quantity and quality are hard to provide, data on length and weight in the nineteenth century suggest that by today's stan-

${ }^{7}$ Knibbe, 'De hoofdelijke beschikbaarheid...', 87. 
Table 5.1 Average annual growth of agricultural production and productivity, 1810-1850

\begin{tabular}{l|l}
\hline Agricultural production & 0.6 \\
\hline Labour productivity & -0.2 \\
\hline Production per hectare & 0.4 \\
\hline Total population & 0.8 \\
\hline
\end{tabular}

Source: J.L. van Zanden, 'Mest en ploeg', in: H. Lintsen et al. (ed.), 'Geschiedenis van de techniek in Nederland. De wording va een moderne samenleving 1800-1890 (Zutphen 1992), Part

1, Table 2.2, 67

dards large parts of the population were insufficiently and poorly fed. ${ }^{8}$ And not only the poor, but also workers, carpenters, petty tradesmen, hired hands, in short 'the people,' the 'masses,' 'the working population - in other words, the 'third estate.'

The food supply could have been improved by certain structural changes in the food supply chain. Changes in the food supply chain were in any case endemic. Markets, scarcity and price influenced the choices of farmers, entrepreneurs, tradesmen and consumers. The purchasing power of the population determined the composition of the daily menu and in this way influenced the supply chain. By means of taxation and legislation the government influenced the production, sale and consumption of food. Many changes had a temporary character. We focus here on the structural changes in the food supply chain and take as our point of departure innovations in food production and consumption. To what extent can we speak of innovations in the agricultural sector, food processing industry and food consumption?

The Netherlands had a difficult time feeding its own population with the natural capital at hand. Agricultural productivity did not keep pace with population growth as is clear from Table 5.1. Even in years of high grain prices, such as 1817, grain production increased inadequately. In other words, there was little elasticity in the grain supply. Agricultural production responded only marginally to changes in demand and the development of agricultural prices.

Why did crop farming respond so feebly to the increasing demand? ${ }^{9}$ An important factor was the surface area of the available agricultural land. This increased inadequately. It is true that the Netherlands possessed extensive heath moors - the 'wastelands' - but these already played an important role in the agricultural system, namely the production of fertilizer and this was a crucial bottleneck. Reclamation and transformation into crop fields and grassland was possible. But then this bottleneck first had to be solved. That proved impossible before 1850. The consequence

\footnotetext{
${ }^{8}$ See for the relationship between nutrition and length/weight: J.J.A. de Beer, Voeding, gezondheid en arbeid in Nederland tijdens de negentiende eeuw. Een bijdrage tot de antropometrische geschiedschrijving (Utrecht 2001).

${ }^{9}$ See for the following: J.L. van Zanden, 'Mest en ploeg', in: H. Lintsen et al. (ed.), 'Geschiedenis van de techniek in Nederland. De wording van een moderne samenleving 1800-1890 (Zutphen 1993), Part 1, 52-61.
} 
was that agricultural production could only be augmented by increasing the productivity per hectare (farming lands plus 'wastelands'). That in fact took place and suggests the development of new farming techniques. To trace this we look at innovations in crop farming.

Inspired by reform movements in England and France in the second half of the eighteenth century, the Netherlands had launched an offensive to renew its agriculture just after the turn of the century. The first 'minister of agriculture' (1805) and the founding of provincial Agricultural Commissions were intended to promote 'scientific' agriculture. These initiatives had little effect. A second offensive in the 1830s and 40s was more successful. It included the founding of a number of provincial agricultural societies, the first Dutch Agricultural Congress (1846), experimentation with new farming methods and the publication of periodicals like Vriend van de Landbouw (Friend of Agriculture) including descriptions of experiments.

A characteristic of the movement was the dominance of local elites of lawyers, politicians, large landowners, and farming gentry. Smallholders did not participate in the agricultural societies. In 1850 the members of all the agricultural societies together totalled some 10,000, while the number of dirt-farmers and smallholders was many times greater. The movement, in pursuit of a 'scientific' agriculture, searched among other things for alternatives to the traditional method of fertilizing the soil: cattle manure supplemented by peat sods from the moors, urban waste and industrial waste products, including earth-foam (aphrite) from the genever distilleries, bone-meal, and fish waste). ${ }^{10}$ In the 1840 s a new fertilizer became available: guano. This was dried sea-bird manure found in meters-thick layers off the coast of Peru. Two years after successful experiments in England a number of farmers and large landowners in the Netherlands followed suit. The results were published in agricultural reports and in a journal like the Tijdschrift ter bevordering van nijverheid (Journal for the promotion of industry).

Not long after, practical experiments with guano became more widespread. The advantage of the new fertilizer was the concentration of active ingredients. Relatively small amounts (compared to classic fertilizers) of guano were already effective. That also meant lower transport costs and less work to fertilize the land. The problem was that results were mixed and that the debate did not resolve the question of the advantages of guano. Fundamental insight into the workings of fertilizer was lacking. Justus von Liebig had only just published his Die organische Chemie in ihrer Anwendung auf Agricultur und Physiologie (Organic Chemistry in its Application to Agriculture and Physiology) (1840). His theories still wanted diffusion and widespread acceptance. Moreover, developments in the price and quality of guano left much to be desired. Prices climbed while quality declined due to

\footnotetext{
10 'Scientific' agriculture for example also embraced the idea that farming had to be industrialised. This included among other things a shift toward mechanisation, steam technology and large-scale enterprises. This is the context in which J.P. Amersfoordt, lawyer and gentleman farmer at the Badhoeve in the Haarlemmermeer Polder, experimented with a steam plow in the 1860s. It became crystal clear that the plow, mounted on a steam locomobile managed by three men and three boys, was not an option for a farmer with only a few hectares of land.
} 
import of inferior guano from other regions and to malversations. Large landowners working on an experimental basis and gentry-farmers could deal with these disadvantages, but for the small farmers the new alternative was hardly appealing. They had few reserves and were not in a position to take risks. The diffusion of guano remained limited, even after 1850.

Moreover, in the first half of the nineteenth century, the smallholders on the sand grounds had been able to increase the yield per hectare. Among other things, they succeeded in fighting weeds more effectively and in improving the manure production of their cows. Their reform strategy consisted of incremental innovation. Though this strategy demanded more labour, that was the one thing in plentiful supply. A growing population and increased employment went hand in hand.

In addition to innovation in agriculture, innovation in the food-processing industry could also have improved popular nutrition. Various initiatives had been taken in other countries. ${ }^{11}$ Steam power had penetrated into various production processes as a substitute for classical sources of energy (wind, water, and horse). It was applied in grain milling, bread baking and beer brewing. Moreover, different industries exhibited all kinds of branch-specific innovations.

In the grain milling industry, for example, in addition to implementing new milling methods, entrepreneurs also devised new installations for purifying the grain and for cooling the flour as well as transport mechanisms for moving the grain and intermediate products from one stage to another. Equipped with these innovations a grain mill assumed the character of a flour factory. A number of these factories already functioned in France, England, the United States and Austria; some in combination with a mechanized bread bakery so that one could speak of a bread and flour factory. ${ }^{12}$

There were certainly efforts to innovate, as the example of Cantillon and the steam grain mill shows, but the majority failed. Innovations in the food processing industry were limited to a small number of branches among which sugar refining. In the 1830 s this branch of industry was still in thrall to small-scale traditional manufacture; by the 1860s large-scale industrial production had become the norm. ${ }^{13}$ Frontrunners invested in new purification methods, steam-heating and vacuum kettles. Steam engines were used to power the pumps. The big investments in expensive machines and building returned a profit only if huge amounts of raw sugar could be processed. The Nederlandse Handel-Maatschappij (Dutch Trading Company) was responsible for the supply from the Dutch East Indies and also extended large credits to entrepreneurs.

\footnotetext{
${ }^{11}$ See for an extensive treatment of innovations in the food processing sector: 'Landbouw en voeding', H. Lintsen et al. (ed.), 'Geschiedenis van de techniek in Nederland. De wording van een moderne samenleving 1800-1890 (Zutphen 1992), Part 1, 37-277 in particular the chapters 'Voeding in Nederland' (by M. Bakker, 38-51), 'Meel' (by H. Lintsen and M. Bakker, 70-101), 'Boter' (by M. Bakker, 102-133), 'Bier' (by H. Schippers, 170-213), 'Suiker' (by M. Bakker, 214-251) and 'Techniek en voeding in verandering' (by M. Bakker, 252-277).

${ }^{12}$ Small-scale craft enterprises survived this development by shifting to the fabrication of specialty products like candy.

${ }^{13}$ Bakker, 'Suiker', 214-251.
} 
Despite the limited number of innovations in the food processing industry there must have been some productivity increases. The growth of the added value in the food processing industry was about $2.7 \%$ (1816-1850), while the work force in this sector grew by $1.9 \%(1807-1849)^{14}$ (Table 3.4). But an important part of the growth derived from simply adding more grain-millers, bakers, butchers etc. In this way the food processing industry easily succeeded in keeping up with population growth.

Were there changes in patterns of consumption? Food comprised the biggest portion of the budget of an average Dutch household, 55-60\%. ${ }^{15}$ This had remained constant for decades. The most important shift in consumption was a negative one. Butter and cheese appeared less and less frequently - as we noted above - on the Dutch 'menu.' These were shipped in huge quantities to foreign consumers. The food package therefore seemed to be getting more meagre. It is difficult to get this clearly in focus. It is true that potatoes and grain products (in particular bread) were the staples of the Dutch diet, but the latter varied throughout the country and depended strongly on the region and residence in the city or the countryside. Many people, moreover, had a vegetable patch in which they grew all kinds of vegetables. The quality of the diet will have been far from adequate, but it was not an issue at the time. The debate concerned the quantity. The social issue was not good food, but enough food for the population.

Structural changes were limited to a very few links in the food supply chain. There was no question of any kind of structural improvement in the food situation. In fact, the situation around 1850 looked quite gloomy - no novelty in the history of the Netherlands. The daily fare of the poor part of the population was meagre, of

\begin{tabular}{|c|c|c|c|c|}
\hline & Growth 1816-30 & Growth $1830-40$ & Growth $1840-50$ & $\begin{array}{l}\text { Growth first half } \\
\text { of the nineteenth } \\
\text { century (estimate) }\end{array}$ \\
\hline $\begin{array}{l}\text { Agriculture value } \\
\text { added }\end{array}$ & 0.60 & 1.43 & 1.20 & $0.7(1816-1850)$ \\
\hline $\begin{array}{l}\text { Agriculture } \\
\text { workforce }\end{array}$ & & & & $0.7(1807-1849)$ \\
\hline $\begin{array}{l}\text { Food processing } \\
\text { value added }\end{array}$ & 4.18 & 2.75 & 0.52 & $2.7(1816-1850)$ \\
\hline $\begin{array}{l}\text { Food processing } \\
\text { workforce }\end{array}$ & & & & $1.9(1807-1849)$ \\
\hline \multirow[t]{2}{*}{ Population } & \multirow[t]{2}{*}{1.16} & \multirow[t]{2}{*}{0.93} & \multirow[t]{2}{*}{0.71} & $1.0(1816-1850)$ \\
\hline & & & & $0.8(1807-1849)$ \\
\hline GDP per capita & 0.42 & 1.41 & 0.81 & $0.8(1816-1850)$ \\
\hline GDP & 1.58 & 2.34 & 1.52 & $1.8(1816-1850)$ \\
\hline
\end{tabular}

Source: van Zanden and van Riel, Nederland 1780-1914, table 4.2, 153

${ }^{15}$ E. Horlings and J-P. Smits, 'Private consumer expenditure in the Nethetlands, 1800-1913, Economic and Social History in the Netherlands 7(1995), Graph 3, 24. 
poor quality and from time to time insufficient. Initiatives to improve this sustainability issue met with little success.

\subsection{Building Materials and Construction: King and State}

The supply chain of building materials was also directly related to the issue of poverty. The chain also touched on other themes of well-being and sustainability. The building materials supply chain can be divided into three categories: housing construction, hydraulic engineering and the construction of infrastructural works. Housing construction (including commercial and public buildings) concerns a broad range of buildings, including public housing for the poor. How problematic was the housing situation of the poor? Were there initiatives to improve their lot? And housing construction raises the issue of hygiene. Poor public health was closely associated - as we saw - with poor hygiene in houses and cities. What happened in this domain around 1850? Hydraulic engineering was concerned with the vulnerable delta, the struggle against water. What policies were developed in order to deal with this important sustainability issue? The construction of infrastructural works (roads, waterways and railroads) has a direct relationship with the sustainability issue. These infrastructures were important for trade and the economy. Did they lay a foundation for prosperity robust enough to solve the issues of poverty and vulnerability? We arrive at the following overview.

\subsubsection{Public Housing and Public Health}

About the housing of the poor and the hygienic measures we can be brief. By today's standards housing and hygiene were very problematic. This conviction was not shared by the contemporaries of 1850 , with the exception of the hygienists, a small intellectual elite of engineers, architects and physicians. ${ }^{16}$ The hygienists developed a judicious program to improve housing. But in the years around 1850 this came to nothing.

Typical for the time is the fate of an 1854 report by the Royal Institute of Engineers, Report to the King, on the requirements and design of workers' hous-

\footnotetext{
${ }^{16}$ For the vanguard role of hygienists, engineers and architects, see: H. van Zon, 'Openbare hygiëne', in: H. Lintsen et al. (ed.), Geschiedenis van de techniek in Nederland. De wording van een moderne samenleving 1800-1890 (Zutphen 1993), Part II, 57; E.S. Houwaart, 'Medische statistiek', in: H. Lintsen et al. (ed.), Geschiedenis van de techniek in Nederland. De wording van een moderne samenleving 1800-1890 (Zutphen 1993), Part II, 27-28. For the perception of contemporaries see the results of research in the internet newspaper archive Delpher in H. Lintsen and T. Lintsen, Opvattingen over hygiëne 1830-1850 (research report Eindhoven University of Technology, 2017).
} 
ing. ${ }^{17}$ It was written by a commission consisting of three architects, a physician and an engineer of the national Public Works Agency (Rijkswaterstaat). It is not clear what prompted the report, but possibly the members of the commission had been inspired by the British Society for Improving the Condition of the Labouring Classes, founded in 1844, and by the London World Fair of 1851, at which Prince Albert's Model-homes were on exhibit. ${ }^{18}$

Be that as it may, the commission's work was the first effort to arrive at an assessment of workers' housing, or more broadly, the 'less fortuned estate', in short, the poor. Though it was based on a sample of neighbourhoods in six cities (Amsterdam, Rotterdam, The Hague, Utrecht, Arnhem and Delft) the conclusions, in view of what subsequent investigations revealed, will not have been much different for other cities. The picture they painted was, in a word, shocking.

The poor lived packed into small, primitive quarters with little light and fresh air and with holes in roofs and floors. The rooms were inevitably damp, drafty, filthy and full of smoke. They were sometimes half buried in the ground and were accessible only from narrow alleyways, into which sunlight barely penetrated, where mounds of garbage lay strewn about and the faeces of the residents remained for days on end. The poor lived like animals:

Alas! The burrows of the people - and no other name suits the homes of many in the less fortuned estate - are not seldom inferior to the places reserved for the housing of animals: the primary requirements for life and health are absent; everything seems arranged to maintain the moral life led in those burrows at the animal level, and hence those burrows, as inexhaustible sources of depravity, inhibit all mental and above all moral development, and stand in the way of the progress of an important class of society... ${ }^{19}$

The poor city-dweller was a caveman. Other sources reveal that the condition of the rural poor was not much different, except that his home was not built of bricks and wood, but of clay, peat, or loam with a roof of reeds or branches. It is estimated that at least 130,000 houses in the Netherlands (of a total of about 620,000) answered to this description in whole or in part. ${ }^{20}$

\footnotetext{
17 'Verslag aan den Koning, over de vereischten en inrigting van arbeiderswoningen, door eene commissie uit het Koninklijk Instituut van Ingenieurs', Het Tijdschrift van het Koninklijk Instituut van Ingenieurs, 1854-1855, 50-75, with 15 illustrations.

${ }^{18}$ A. van der Woud, Koninkrijk vol sloppen: Achterbuurten en vuil in de negentiende eeuw (Amsterdam 2010); H. Buiter and H.W. Lintsen, 'De stad, de stank en het water', in: H.W. Lintsen (Ed.), Made in Holland: Een techniekgeschiedenis van Nederland [1800-2000] (Zutphen 2005), 90.

19 'Verslag aan den Koning, over de vereischten en inrigting van arbeiderswoningen', 4.

${ }^{20} \mathrm{Hole}$, shack, hovel and slum are qualitative terms. Around 1850 the government did little or nothing in the way of investigating housing quality. Such investigations are of a later date. Dwellings that did not meet specific criteria could be endowed with such labels. Criteria shifted in the course of time. Having a privy in or near the dwelling, being connected to a public water supply, or having heating could be criteria, just like light, air and space as the traditional indicators of quality. These norms could be set ambitiously or be light as a feather. In the latter case hovels were dwellings that should actually already have been demolished; in short, dwellings that later appeared on the list of uninhabitable buildings and where the uninhabitability was no longer at issue. It was also possible to opt for a stringent norm which left the better part of the available housing beyond the pale. It goes without saying that the figures pertinent to each approach would differ wildly.
} 
It is notable that the commission for the first time introduced norms to which workers' housing was to conform: sufficient space, sufficient light and fresh air with potable water and sanitary facilities. This was translated into a series of designs. It is typical of the period that nothing was done with them. King William II was not the kind of person to be concerned about these kinds of issues. The problem was moreover not the business of the central state, but of the municipalities. What is even more telling is that the bourgeoisie was anything but concerned about housing the poor. The same held for poor relief. A room and roof above one's head were considered enough.

The investigation into workers' housing can also be seen as a new approach to the problem of hygiene. This too was of little interest to the bourgeoisie. ${ }^{21}$ It viewed hygiene from the classic vantage point of cleanliness: a clean home, a spotless kitchen, a scrubbed sidewalk, clean clothes, clear water. Hygiene also included a 'calm cheerful disposition ...' and 'a firm trust in God's Providence.' Much attention was paid to pure air and smelly fumes because according to the miasma theory infectious diseases were communicated chiefly through the air. Rotting substances, spoiled food and stagnant water had to be avoided. Homes needed to be ventilated, canals flushed and garbage cleaned up. Hygiene in public spaces was subject to stringent regulations but these were quite ineffective. Local governments lacked the wherewithal to monitor their observance. The bourgeoisie had an inadequate sense of public hygiene as a serious social problem and treated the issue '... in general in an inattentive, imprecise, careless, yes, reckless fashion...' as an inventor of ino-

We derive an estimate of the number of hovels around 1850 from the following calculation:

- In 1856-1857, 362,159 dwellings and 12,160 warehouses were taxed. 257,706 dwellings were not taxed. Total: 632,025 dwellings and warehouses. The tax officials counted 619,865 dwellings. Of these, $42 \%$ was not taxed and $58 \%$ was taxed.

- Using other sources, Duyndam calculated: 680,000 dwellings in the Netherlands. This is a difference of about 60,000 dwellings, or $\pm 9 \%$.

- Points of departure in this study:

Number of dwellings: 619,865

Number of inhabitants in the Netherlands 3,115,421

Average number of persons per dwelling: 5

Non-taxed dwellings are in large part qualitatively inferior dwellings.

- Non-taxed means a rent-value below fl. 18/year for 257,706 dwellings, or 42\%

Around 1850 about $7 \%$ is paid for rent.

Maximum annual income for residents of non-taxed dwellings: fl. 257 per dwelling

- Maximum annual income per capita in non-taxed housing fl. 51

- $42 \%$ of the inhabitants has on average an annual income less than fl. 51.

- $21 \%$ of the inhabitants of the Netherlands lives below the poverty line of fl. 43 year consumptive expenditures. This amounts to 658,000 inhabitants in 131,600 dwellings (on average 5 persons per dwelling). We assume that these are certainly qualitatively poor dwellings.

- Conclusion: at least 130,000 and at most 260,000 dwellings are of poor quality.

${ }^{21}$ See H. Lintsen and T. Lintsen, Opvattingen over hygiëne 1830-1850 (research report Eindhoven University of Technology, 2017). 
dores (non-smelling privies) and urinoirs complained..$^{22}$ To be sure there were complaints about smells, but more in terms of nuisance than as a threat to health. Something similar applied to drinking water from wells, canals and rivers. It was considered to be of poor quality and the population therefore drank plenty of beer. The complaints were mostly about the smell and the taste. The citizens were little concerned about public health. Cholera was one of the few diseases that frightened governments and citizens and got them thinking about radical changes. The disease broke out in 1848, but after a few years the unrest had passed.

The new approach advocated by the hygienists put a high value on scientific research. ${ }^{23}$ They were the first to gather medical statistics. They stressed the salience of drinking water and fecal wastes. Proposed solutions were piped water and sanitary facilities in the home and public hygienic facilities on the street. Government should assume responsibility for hygiene and provide the necessary means and personnel. The commission appointed by the Royal Institute of Engineers was an exponent of a new generation of the bourgeoisie that would begin to exert influence only after the mid-nineteenth century.

\subsubsection{Water Management}

Hydraulic engineering faced an entirely different challenge. It had to respond to the risks associated with living in a delta. Storms and river floods regularly threatened chattels and goods of the Dutch. New impulses for dealing with this sustainability problem emerged in the wake of new relationships in the domain of water management.

For centuries water management had been the business of water boards, local government and provinces. During the Batavian and French period (1795-1813) the contours of a unified state were forged and the central state acquired supervisory authority over the entire domain of water management as well as direct responsibility for a number of sea and river works of national importance. ${ }^{24}$ This introduced a new actor into the sphere of water management. Between 1813 and 1840 this coincided with the person of King William I. The Rijkswaterstaat was his executive agency. Major projects required enormous amounts of tax money, persuasive power and credibility. These the King could deliver. The Rijkswaterstaat was able to mobilise and organise knowledge, large quantities of materials and masses of labourers.

\footnotetext{
${ }^{22}$ De Noord-Brabanter: staat- en letterkundig dagblad 07-07-1949.

${ }^{23}$ E.S. Houwaart, 'Professionalisering en staatsvorming', in: H.W. Lintsen et al. (Eds.), Geschiedenis van de techniek in Nederland: De wording van een moderne samenleving 1800 1890 (Zutphen 1993), Part II, 82-85.

${ }^{24} \mathrm{H} . \mathrm{W}$. Lintsen, Ingenieurs in Nederland in de negentiende eeuw: Een streven naar erkenning en macht (proefschrift Technische Universiteit Eindhoven 1980), 45-64; A. Bosch and W. van der Ham, onder redactie van H.W. Lintsen, Twee eeuwen Rijkswaterstaat 1798-1998 (Zaltbommel 1998, eerste druk), 33-41.
} 
Perennial floods, as we have seen, were among the biggest problems of the period. In fact these had been one of the main reasons for founding the Rijkswaterstaat in 1798. But however urgent the problem might have been, solutions were not forthcoming. The main impediment was a shortage of river mouths. Close to the sea the river system formed a kind of bottleneck that encouraged enormous obstructions when the rivers were high and clogged with ice floes. But the construction of new river mouths was a gigantic enterprise which even the King and the Rijkswaterstaat refused to risk undertaking. ${ }^{25}$

Another impediment was the nature of the river. The Dutch river was a so-called 'green river,' a river with islands, sandbanks, brushwood, reeds, swamp forests, and other vegetation along the river banks. It did not possess a single channel, but a braided system of channels. The narrow channels frustrated a rapid discharge at high water and encouraged the formation of ice blockages and ice dams when ice floes clogged the rivers. Possible solutions were the subject of chronic debates. ${ }^{26}$

Some hydraulic engineers looked to lateral diversions using overbank floodways. These consisted of a number of dike sections that had been lowered to allow the river at high stages to spill into a floodway. This created artificial floods and directed the excess water to another river or to a downstream section of the same river. In other words, the system of channels was temporarily expanded.

Other engineers regarded the preservation and elaboration of the 'classical green river' as a thorn in their sides. They viewed the lateral diversions as a 'soothing plaster on a filthy stinking wound.' According to them the problem was only being displaced, while a fundamental approach was needed, namely 'normalization' of the rivers. A 'normalized' river no longer flowed through a system of channels, but through one continuous channel maintained at fixed dimensions and in itself able to discharge the necessary water and ice into the sea.

The two governmental commissions appointed by William I could not arrive at a consensus. Added to this was the fact that the King did not prioritize the rivers and preferred to spend money on canals and other plans. After the war with Belgium between 1830 and 1838 funds for hydraulic projects were in any case lacking.

A big project backed by the King that did succeed was the reclamation of the Haarlemmermeer. Public safety, the continual loss of land and the destruction of goods were important arguments for the reclamation. Nonetheless these were not of overriding importance for the definitive decision to eliminate the threat constituted by the lake. More to the point was the fact that the reclamation enacted the politics of welfare-promotion pursued by William I. The gigantic enterprise provided work for thousands of families. It also delivered an enormous expanse of new farming land with which to feed the realm and grow export products. In 1837 the King appointed a governmental commission to deliberate on the reclamation. In 1839 a

\footnotetext{
${ }^{25}$ H.W. Lintsen and A. van Heezik, 'In gevecht met de rivieren', in: H.W. Lintsen et al., Made in Holland: Een techniekgeschiedenis van Nederland [1800-2000] (Zutphen 2005), 98.

${ }^{26}$ Zie voor het navolgende: A. van Heezik, Strijd om de rivieren: Tweehonderd jaar rivierenbeleid in Nederland of de opkomst en ondergang van het streven naar de normale rivier (dissertation TUDelft 2007).
} 
law was adopted mandating a reclamation by the state. Thousands of workers constructed the encircling dike and the accompanying drainage canal - also intended as a waterway for inland navigation. Three enormous steam engines (the most powerful in the world at that time) - the Cruquius, the Lijnden and the Leeghwater pumped the lake dry. The job was completed by 1853 .

\subsubsection{Infrastructure ${ }^{27}$}

King William's big ambition was to improve the welfare of his people. The theme recurred in all his King's speeches. The state represented the public good and was beholden to pursue the greatest happiness for the greatest number. The impoverished Netherlands had to be revived with diligence and industry and with useful knowledge and projects. The development of infrastructure was a crucial feature of his politics. This was essential for prosperity, but also for unity. Prosperity demanded unification of the country, politically, economically and culturally. Decent infrastructure was one of the preconditions. The King went to work with a will.

It is true that thanks to its extensive network of waterways the Netherlands already had one of the best transport infrastructures in the world, but that was true only for the western part of the country. The eastern Netherlands were poorly integrated. Moreover, other countries like England and Belgium were busy improving their infrastructures with roads and canals. And then there were also the railways as revolutionary means of transport. The harbours of Amsterdam and Rotterdam were threatened with the loss of their unique position due among other things to competition from Antwerp and Hamburg.

During the reign of William I, for the first time, a coherent network of roads with international connections came into being. Initially the national state had instigated the project. Provinces, municipalities and private capital followed with refinements to the network, that ultimately connected all regions of the country. ${ }^{28}$

William I also invested in the construction of canals. This did not eventuate in a coherent network. Every canal had its own purpose. The North-Holland Canal and the Voornse Canal, for example, were dug to improve access to the maritime harbours of, respectively, Amsterdam and Rotterdam. The Dedemsvaart and the Willemsvaart were constructed to facilitate the transport of turf. The ZuidWillemsvaart served to incorporate the eastern part of North Brabant and a part of Limburg into the rest of the waterways system. Canal construction was above all an extension of William I's economic politics with its high priority for international trade followed by the promotion of agriculture, industry and jobs. ${ }^{29}$

\footnotetext{
${ }^{27}$ Zie voor deze paragraaf: G. Mom and R. Filarski, Van transport naar mobiliteit: De transportrevolutie [1800-1900] (Zutphen 2008).

${ }^{28}$ William I's policy extended initiatives already started in the French and Batavian period (17951813). Mom and Filarski, Van transport naar mobiliteit, 108.

${ }^{29}$ Mom and Filarski, Van transport naar mobiliteit 112-115, 123.
} 
Only two railways were built under William I. One between Amsterdam and Rotterdam and the so-called Rhine Railway. The first was intended as an attractive alternative for the existing goods and passenger transport between the two harbours. The second, intended to connect Amsterdam with the German hinterland, was the anxious answer to the railway line between Antwerp and Cologne.

Many projects encountered resistance and engendered heated debates. The construction of a road, canal or railway disrupted the status quo. The choice of a route threatened local interests, strained property rights and disturbed long-standing practices. The route could also be contested because it literally bypassed municipalities and deprived them of the benefits of the new infrastructure. Some actors had problems with new technologies. Many of the above issues came to the fore with the construction of the railway between Amsterdam and Rotterdam. Opponents considered the railway completely superfluous. Existing infrastructure was more than adequate. They could not imagine that the population had any need for this modern mode of transport. The railways would barely show a profit. Quite the contrary, the railways would seriously harm local interests.

Stable owners, barge haulers, shipping agencies, certifiers, delivery services, ships' carpenters, shipbuilders would naturally suffer a large and important loss. And then we do not even speak of stage-coach entrepreneurs and everything associated therewith. ${ }^{30}$

The choice of a route had to take the interests of national defense into account; owners of land needed for the right of way bargained with the railway company for extra stations, etc. It was only royal will-power that endowed the Netherlands with two railways before the middle of the century. ${ }^{31}$

Did all these infrastructural projects augment national welfare, as the King so ardently desired? The question is difficult to answer. Some doubts can, however, be raised. ${ }^{32}$ Economically speaking, the maritime canals were a failure. Canals like the North Holland Canal, the Marken Canal and the Zederikkanaal were barely used and provided far too little revenue to justify the costs of construction. On the other hand, turf canals like the Dedemsvaart and regional access canals like the ZuidWillemsvaart did have the desired social and economic effects. The railways also exhibited a similar dualism. The railway between Amsterdam and Rotterdam was a success from the very start, while the Rhine Railway became a drama and financially speaking a bottomless pit. ${ }^{33}$

The impact of new roads leads to some interesting speculations. The main roads in the region bounded by Amsterdam, Rotterdam and Utrecht were sufficiently profitable from a socio-economic point of view. But what about the situation in the peripheries? It is noteworthy that road transport in the (relatively sparsely settled) provinces of Gelderland, Overijssel and Drenthe increased significantly. ${ }^{34}$ The same

\footnotetext{
${ }^{30}$ Quoted in: Mom and Filarski, Van transport naar mobiliteit 129.

${ }^{31}$ Mom and Filarski, Van transport naar mobiliteit, 149.

${ }^{32}$ Mom and Filarski, Van transport naar mobiliteit, 381-383.

${ }^{33}$ Mom and Filarski, Van transport naar mobiliteit 361-378 in particular 373-378.

${ }^{34}$ J.L. van Zanden, De economische ontwikkeling van de Nederlandse landbouw in de negentiende eeuw, 1800-1914 (dissertation Universiteit Wageningen 1985), 148-149.
} 
held for North Brabant and Limburg. In Drenthe, for example, the number of farmwagons and carts increased from about 2880 in 1818 to 9400 in 1854. Transport costs declined by $50 \%$ to possibly $75 \%$. Small farmers were able to earn extra money in the transport business. Markets were more accessible. Agricultural products found markets over larger areas. The cottage textile industry flourished. Earlier we concluded that after 1820 poverty in the Netherlands declined precipitously and proposed as cause de-urbanization and the rise of the country-provinces, in particular on the sand grounds. The prerequisite would then be the improved accessibility of those regions thanks to the construction of a rural road system.

If this analysis holds water, then the development of infrastructure did stimulate national welfare, but in a different way than imagined by William I. It was not the powerful cities of Amsterdam and Rotterdam that contributed to national welfare but the countryside and the small cities on the sand grounds. ${ }^{35}$ Economic growth was rooted not in industrialization and large-scale production on the English model, but in a commercializing agriculture and cottage industry in the former periphery. That said, it remains the case that William I's efforts did lay the groundwork for a transport revolution in the following period, a revolution that also affected national welfare.

Around 1850 housing construction, water management and infrastructure were the three relevant themes of the building materials supply chain in relation to sustainability. It was only in the domain of infrastructure that dramatic changes took place. These had an unexpected effect on the question of poverty.

To conclude, we examine the third supply chain, that of the fossil raw materials. What changes took place here?

\footnotetext{
${ }^{35}$ Using a gravity model, J. de Vries analysed the historical structure of the Dutch 'Randstad' (urban agglomeration in the western Netherlands). He applied this to the passenger traffic serviced by the Hollandsche Yzeren Spoorweg Maatschappij (Holland Iron Railway Company) in 18571861 and contrasted this pattern with that of the tow-barges of the seventeenth and eighteenth centuries. The balanced urban system of the Golden Century - in reality a collection of highly autonomous cities and towns - had disappeared. Amsterdam was originally dominant but stagnated as far as passenger traffic was concerned. That made room for other cities. Passenger traffic on the railroad showed that Rotterdam and subsequently The Hague were secondary centers and that they moreover bound relatively many smaller cities to themselves. In 1855 Amsterdam had only one satellite city, Haarlem, while Rotterdam had four. This development had roots reaching back to the period before 1800. The period 1700-1750 was that of the (Holland) urban system in decline. The period 1750-1800 that of the dual city system, the rise of rivals to Amsterdam. J. de Vries, 'Barges and capitalism: Passenger transportation in the Dutch economy, 1632-1839', in: A.A.G. Bijdragen 21 (1978), 252-351.
} 


\subsection{Energy: Coal and Steam ${ }^{36}$}

The promotion of national well-being could be pursued along different paths. There were three options, as we showed in the previous chapter: diminution of social inequality, economic growth with the aid of domestic natural capital and economic growth with the aid of natural capital elsewhere, in particular in the Dutch East Indies. William I's infrastructural policy, in particular on the point of roads, enabled a combination of the three options. The sand grounds and the high moors - previously relegated to the periphery - could now develop and be integrated into the national economy and the colonial complex. The rapidly growing population in those regions experienced less social inequality than the urban population.

Economic growth with the aid of natural capital could take place in the first half of the nineteenth century in yet another way, namely by radical changes in the supply chain of fossil raw materials. The output of an economy is in its most elementary form reducible to a function of capital and labour. ${ }^{37}$ Both capital and labour require inputs of energy to realise an output. For labour (human and animal force) the source of energy is food. In an agricultural economy the production of food is limited by the availability of fertile ground and the transformation of sunlight into agricultural produce. For capital, sources of energy are the sun, the wind, water and fossil and nuclear raw materials. These can, in principle, break the bonds of an economy based on labour and land. Wind, water and turf already do this in the preindustrial phase. For centuries, the Netherlands had already been exploiting wind power and turf on a large scale - to great economic effect. The breakthrough of the nineteenth century is the use of the fossil fuel coal in combination with the steam engine. ${ }^{38}$

Prominent contemporaries in the first half of the nineteenth century were already convinced of the crucial role of coal and steam. Anthony Hendrik van der Boon Mesch, professor of chemistry and later president of the University of Leiden, put it like this in 1843:

The Government and the Nation, we see both...exerting their powers, to the end of recovering as much as possible of what has been lost and to expansion into a field hitherto unexplored... The introduction of steam engines...breathes new life and importance into many manufactures. Much of what was considered to be possible only in England, is now happening here. ${ }^{39}$

\footnotetext{
${ }^{36}$ See for this section: H. Hölsgens, Energy transitions in the Netherlands: Sustainability challenges in a historical and comparative perspective (dissertation Rijksuniversiteit Groningen 2016), chapter 1, 1-18 and chapter 2, 19-60; H.W. Lintsen, 'Een land met stoom', in: H. Lintsen et al. (ed.), Geschiedenis van de techniek in Nederland. De wording van een moderne samenleving 1800-1890 (Zutphen 1993), Part VI, 191-209

${ }^{37}$ Hölsgens, Energy transitions in the Netherlands, 4-6.

${ }^{38} \mathrm{On}$ the limitations of land and labour in relation to economic growth: E.A. Wrigley, Energy and the English Industrial Revolution (Cambridge 2010); Sieferle writes about the 'subterranean forest' when writing about fossil sources of energy: R. Sieferle, The subterranean forest: Energy systems and the Industrial Revolution (Cambridge 2001).

${ }^{39}$ Quoted in: Hölsgens, Energy transitions in the Netherlands, 9.
} 
Table 5.2 Energy use in the Netherlands per source of energy in 1850

\begin{tabular}{l|l|l}
\hline & TJ & Percentage \\
\hline Human and animal & 33,500 & 38 \\
\hline Turf & 21,900 & 25 \\
\hline Coal & 14,300 & 16 \\
\hline Wood & 9800 & 11 \\
\hline Wind and water & 9000 & 10 \\
\hline Total & 88,500 & 100
\end{tabular}

Source: B. Gales and H. Hölsgens, 'Energy consumption in the Netherlands (1800-2012)', in: H. Hölsgens, Energy transitions in the Netherlands. Sustainability challenges in a historical and comparative perspective (dissertation Rijksuniversiteit Groningen 2016), Table A.I.1, 211

\begin{tabular}{l|l|l}
\hline & Number & Percentage \\
\hline Windmills & 3050 & 53 \\
\hline Horse treadmills & 1930 & 34 \\
\hline Watermills & 470 & 8 \\
\hline Steam Engines & 290 & 5 \\
\hline Total & 5470 & 100
\end{tabular}

Source: H. Lintsen, 'Een land met stoom', in: H. Lintsen et al. (ed.), Geschiedenis van de techniek in Nederland. De wording van een moderne samenleving 1800-1890 (Zutphen 1995), vol. VI, Table 7.1, 192

In the Netherlands, wind and turf had long-ago occasioned a breakthrough. The economic success of the Golden Century was in part due to the application of the Dutch windmill and the use of cheap turf. The future lay, according to Van der Boon Mesch, in imitation of England, in the steam engine and coal. In his time William I was certainly not alone in his efforts to modernise industry.

The total consumption of energy in the Netherlands in 1850 can be estimated at 88,500 Tera joule (TJ) (Table 5.2). Humans and animals provided the most energy, $33,500 \mathrm{TJ}$ (or $38 \%$ ), followed by turf with 21,900 (25\%). Coal took third place with $14,300 \mathrm{TJ}(16 \%)$ even before wood as a source of energy (9800 TJ or $11 \%$ ) and wind and water (9000 or $10 \%$ ). But these statistics give a wrong impression of the role of coal. In that year coal was used not so much for steam production to power steam engines, but as a source of heat in households and production. This type of use did not occupy centre stage in the process of industrialization.

The number of steam engines in Dutch industry was quite modest in 1850, 290 of a total of 5740 prime movers (5\%). The rest consisted of windmills (53\%) horse treadmills (34\%) and a small percentage of water mills (8\%) (Table 5.3). Why did 
Table 5.4 Costs of depreciation, interest, maintenance, labour and fuel of different sources of energy in industry, $1825-1850$

\begin{tabular}{l|l|l|l|l|l}
\hline Place/region & Overijssel & Overijssel & Amsterdam & Amsterdam & Amsterdam \\
\hline Technology & $\begin{array}{l}\text { Human } \\
\text { power }\end{array}$ & $\begin{array}{l}\text { Water } \\
\text { power }\end{array}$ & $\begin{array}{l}\text { Wind } \\
\text { power }\end{array}$ & $\begin{array}{l}\text { Steam }(m a x . \\
20 \mathrm{hp})\end{array}$ & Horse \\
\hline Period & $1825-1850$ & $1825-1850$ & $1825-1850$ & 1843 & $1825-1850$ \\
\hline $\begin{array}{l}\text { Depreciation, interest and } \\
\text { maintenance }\end{array}$ & & 0.54 & 0.51 & 0.68 & 0.32 \\
\hline Wages & 5.00 & 0.02 & 0.39 & 0.19 & 0.34 \\
\hline Fuel & & 0.33 & & 0.79 & 2.00 \\
\hline Total & 5.00 & 0.91 & 0.90 & 1.66 & 2.75 \\
\hline
\end{tabular}

Source: H. Lintsen, 'Een land met stoom', in: H. Lintsen et al. (ed.), Geschiedenis van de techniek in Nederland. De wording van een moderne samenleving 1800-1890 (Zutphen 1995), vol. VI, Table 7.1, 198

not the supply chain coal mining-coal burning-steam production-steam power develop? What are the reasons for the limited use of steam technology?

Economics provides part of the answer. ${ }^{40}$ For this we compare the steam engine to classical prime movers and regard them as completely interchangeable in the process of production (Table 5.4). In the first half of the nineteenth century the windmill and watermill were the cheapest, after that the steam engine (assuming an engine of about $12 \mathrm{hp}$ ) and finally the horse treadmill and the human body. Compared to the windmill and watermill the steam engine was an expensive source of power. Operating costs were high, among other things because of the cost of coal. ${ }^{41} \mathrm{~A}$ horse suffered from even higher operating costs especially because of the cost of food. But humans were dearest. Considering human food as fuel, and the fact that acquiring this fuel consumed a large part of the worker's wages, he easily became the most expensive prime mover. Nonetheless, humans were hard to replace. Human workers were also clever in utilizing tools and simple machines and could be employed at many places in the process of production. The horse's position was considerably weaker. He would be the first to be ejected from the process of production and managed to retain a position only in transport. It should also be noted that the costs of running steam engines depended strongly on the region. Due to the lack of decent waterways, coal was considerably more expensive in Twente than in Amsterdam. In Twente cottage industries long competed successfully with the textile factory.

The entrepreneur who introduced steam technology prior to 1850 was almost always 'doomed' to higher production. ${ }^{42}$ The steam engine demanded the presence or the creation of a sufficiently large market. In most cases this requirement was not met. That brings us to different kinds of reasons for the limited application of steam

\footnotetext{
${ }^{40}$ Lintsen, 'Een land met stoom', 195-198.

${ }^{41}$ Taxes were levied on coal until 1863. That made coal more expensive than turf. It was true that the entrepreneur could be refunded but that required a long march through the tax bureaucracy. Even without taxes the fuel costs of steam engines were still considerable.

${ }^{42}$ Lintsen, 'Een land met stoom', 199-202.
} 
power in industry. In the countryside, poor transport infrastructure long hindered the expansion of local markets into regional or national markets. Urban markets were dominated by informal cartels of old crafts. The legal system was oriented to smallscale production and hindered large-scale production processes.

The economic structure is another explanatory factor. The Netherlands lacked economically exploitable raw materials like coal and iron ore. Significant mining was lacking, as opposed to England and Belgium. This branch of industry was a crucial domain of application for steam technology. Demand for steam engines to pump water, ventilate mine shafts and transport mine workers and ore stimulated the iron industry and machine engineering.

Mining, the iron industry, machine engineering and the textile industry (and in its wake the sulphur industry) were the dynamic sectors in the industrialization of England and Belgium. These had an enormous impact on the other industrial sectors. The Netherlands lacked mining of any importance. The textile industry was based on cottage production. The metalworking sector was small in scope. Machine engineering consisted of a small nucleus of machine builders. Industrialisation had not started in 1850 and thus neither was the promotion of national welfare on the basis of industrialisation.

\section{Literature}

Allen, R.C. (2013). 'Poverty lines in history: Theory and current international practice'. Discussion paper series. Department of Economics, University of Oxford.

Bakker, M. (1992). 'Boter'. In H.W. Lintsen et al. (Eds.), Geschiedenis van de techniek in Nederland: De wording van een moderne samenleving 1800-1890 (Vol. I, pp. 103-133). Zutphen: Walburg.

Bakker, M. (1992). 'Suiker'. In H.W. Lintsen et al. (Eds.), Geschiedenis van de techniek in Nederland. De wording van een moderne samenleving 1800-1890 (Vol. I, pp. 215-251). Zutphen: Walburg.

Bakker, M. (1992). 'Techniek en voeding in verandering'. In H.W. Lintsen et al. (Eds.), Geschiedenis van de techniek in Nederland: De wording van een moderne samenleving 1800-1890 (Vol. I, pp. 253-277). Zutphen: Walburg.

Bakker, M. (1992). 'Voeding in Nederland'. In H.W. Lintsen et al. (Eds.), Geschiedenis van de techniek in Nederland: De wording van een moderne samenleving 1800-1890 (Vol. I, pp. 39-51). Zutphen: Walburg.

Beer, J.J.A. de (2001). Voeding, gezondheid en arbeid in Nederland tijdens de negentiende eeuw. Een bijdrage tot de antropometrische geschiedschrijving. Utrecht: PhD-study University Utrecht.

Bosch, A., Ham W. van der, and Lintsen, H.W. (1998). Twee Eeuwen Rijkswaterstaat 1798-1998. Zaltbommel: Europese Bibliotheek.

Buiter, H. and H.W. Lintsen (2005). 'De stad, de stank en het water'. In H.W. Lintsen (Ed.), Made in Holland: Een techniekgeschiedenis van Nederland [1800-2000]. Zutphen: Walburg Pers.

'Verslag aan den Koning, over de vereischten en inrigting van arbeiderswoningen, door eene commissie uit het Koninklijk Instituut van Ingenieurs', Het Tijdschrift van het Koninklijk Instituut van Ingenieurs, 1854-1855, 50-75. 
Gales, B. and H. Hölsgens (2016). 'Energy consumption in the Netherlands (1800-2012)'. In Hölsgens, H. (Ed.), Energy transitions in the Netherlands: Sustainability challenges in a historical and comparative perspective (dissertation). Groningen: University of Groningen, SOM research school.

Heezik, A. van (2007). Strijd om de rivieren: Tweehonderd jaar rivierenbeleid in Nederland of de opkomst en ondergang van het streven naar de normale rivier (dissertation). Delft: Technische Universiteit Delft.

Hölsgens, H. (2016). Energy transitions in the Netherlands: Sustainability challenges in a historical and comparative perspective (dissertation). Groningen: University of Groningen, SOM research school.

Horlings, E. and J.P. Smits (1995). 'Private consumer expenditure in the Netherlands, 1800-1913'. Economic and Social History in the Netherlands, 7, 15-40.

Houwaart, E.S. (1993). 'Medische statistiek'. In H.W. Lintsen et al. (Eds.), Geschiedenis van de techniek in Nederland: De wording van een moderne samenleving 1800-1890. Zutphen: Walburg.

Houwaart, E.S. (1993). 'Professionalisering en staatsvorming'. In H.W. Lintsen et al. (Eds.), Geschiedenis van de techniek in Nederland: De wording van een moderne samenleving 1800 1890 (Vol. II, pp. 81-92). Zutphen: Walburg.

Knibbe, M.T. (2007). 'De hoofdelijke beschikbaarheid van voedsel en de levensstandaard in Nederland, 1807-1913'. Tijdschrift voor Sociaal-Economische Geschiedenis, 4, 71-107.

Lintsen, H.W. (1980). Ingenieurs in Nederland in de negentiende eeuw: Een streven naar erkenning en macht (dissertation). Eindhoven: Technische Universiteit Eindhoven.

Lintsen, H.W. (1995). 'Een land met stoom'. In H.W. Lintsen et al. (Eds.), Geschiedenis van de techniek in Nederland: De wording van een moderne samenleving 1800-1890 (Vol. VI, pp. 191-210). Zutphen: Walburg.

Lintsen, H.W. and M. Bakker (1992). 'Meel'. In H.W. Lintsen et al. (Eds.), Geschiedenis van de techniek in Nederland: De wording van een moderne samenleving 1800-1890 (Vol. I, pp. 71-101). Zutphen: Walburg.

Lintsen, H. (2005). Made in Holland: Een techniekgeschiedenis van Nederland [1800-2000]. Zutphen: Walburg Pers.

Lintsen, H.W. and Heezik, A. van (2005). 'In gevecht met de rivieren'. In H.W. Lintsen (Ed.), Made in Holland: Een techniekgeschiedenis van Nederland [1800-2000] (pp. 95-113). Zutphen: Walburg Pers.

Lintsen, H. and T. Lintsen (2017), Opvattingen over hygiëne 1830-1850 Eindhoven: Eindhoven University of Technology, open-access research report

Mom, G. and R. Filarski (2008). Van transport naar mobiliteit: De mobiliteitsexplosie (18952005). Zutphen: Walburg Pers.

Schippers, H. (1992). 'Bier'. In H.W. Lintsen et al. (Eds.), Geschiedenis van de techniek in Nederland: De wording van een moderne samenleving 1800-1890 (Vol I, pp. 171-213). Zutphen: Walburg.

Sieferle, R. (2001). The subterranean forest: Energy systems and the Industrial Revolution. Cambridge: The White Horse Press.

Vries, J. de (1978). 'Barges and capitalism: Passenger transportation in the Dutch economy, 16321839', in: A.A.G. Bijdragen 21, 252-351.

Woud, A. van der (2010). Koninkrijk vol sloppen: Achterbuurten en vuil in de negentiende eeuw. Amsterdam: Bert Bakker.

Wrigley, E.A. (2010). Energy and the English Industrial Revolution. Cambridge: Cambridge University Press.

Zanden, J.L. van (1985). De economische ontwikkeling van de Nederlandse landbouw in de negentiende eeuw, 1800-1914 (dissertation). Wageningen: Universiteit Wageningen. 
Zanden, J.L. van (1992). 'Mest en ploeg'. In H.W. Lintsen et al. (Eds.), Geschiedenis van de techniek in Nederland: De wording van een moderne samenleving 1800-1890 (Vol. I, pp. 53-69). Zutphen: Walburg.

Zanden, J.L. van en Riel, A. van (2000). Nederland 1780-1914. Staat, instituties en economische ontwikkeling. Amsterdam: Balans.

Zon, H. van (1993). 'Openbare hygiëne'. In H.W. Lintsen et al. (Eds.), Geschiedenis van de techniek in Nederland: De wording van een moderne samenleving 1800-1890 (Vol. II, pp. 47-79). Zutphen: Walburg.

Open Access This chapter is licensed under the terms of the Creative Commons Attribution 4.0 International License (http://creativecommons.org/licenses/by/4.0/), which permits use, sharing, adaptation, distribution and reproduction in any medium or format, as long as you give appropriate credit to the original author(s) and the source, provide a link to the Creative Commons license and indicate if changes were made.

The images or other third party material in this chapter are included in the chapter's Creative Commons license, unless indicated otherwise in a credit line to the material. If material is not included in the chapter's Creative Commons license and your intended use is not permitted by statutory regulation or exceeds the permitted use, you will need to obtain permission directly from the copyright holder. 